At-Tijaroh : Jurnal Ilmu Manajemen dan Bisnis Islam

\title{
ANALISIS FAKTOR-FAKTOR YANG MEMENGARUHI ASET BPRS
}

\author{
Muhammad Ikhsan Harahap ${ }^{1}$, Rahmat Daim Harahap² \\ 1,2Universitas Islam Negeri Sumatera Utara \\ 1,2Jl. Willem Iskandar Pasar V Medan, Sumatera Utara \\ ${ }^{1}$ m.ihsan.harahap@uinsu.ac.id \\ 2 rahmatdaimharahap@uinsu.ac.id
}

\begin{abstract}
Sharia Rural Banks (BPRS) are one of the sharia financial institutions that function the same as Sharia Commercial Banks (BUS) and Sharia Business Units (UUS), only BPRS have fewer assets compared to more economical and micro BUSs. There is some empirical evidence that affects the assets of the claimed BPRS, namely Inflation, Bank Indonesia Interest Rate (BI Rate), Equivalent Rate, and Return on Asset (ROA) ratio. This research is quantitative research, with multiple linear regression analysis that is processed using software Eviews 8. The results of the research are obtained from the valuation and the level of Equivalent to BPRS assets, while the BI rate and ROA affect the assets of the BPRS. Overall, the independent variable affect the assets of the BPRS.
\end{abstract}

Keyword : Asset, Equivalent Rate, BPRS.

\section{Abstrak}

Bank Perkreditan Rakyat Syariah (BPRS) merupakan salah satu lembaga keuangan syariah yang fungsinya sama dengan Bank Umum Syariah (BUS) dan Unit Usaha Syariah (UUS), hanya saja BPRS memiliki aset yang lebih sedikit jika dibandingkan dengan BUS sehingga fokus pembiayaannya hanya pada sektor kecil dan mikro. Ada beberapa bukti empiris yang memengaruhi asset BPRS diantaranya yaitu Inflasi, Suku Bunga Bank Indonesia (BI Rate), Equivalent Rate, dan rasio Return On Aset (ROA). Penelitian ini adalah penelitian kuantitatif, dengan analisis regresi linier berganda yang diolah dengan menggunakan software Eviews 8. Hasil penelitian diperoleh bahwa inflasi dan Equivalent Rate berpengaruh terhadap aset BPRS, sedangkan BI rate dan ROA tidak berpengaruh terhadap asset BPRS. Secara simultan seluruh variabel bebas berpengaruh terhadap aset BPRS.

Kata Kunci : Aset, Equivalent Rate, BPRS.

\section{PENDAHULUAN}

Bank Syariah didirikan dengan tujuan untuk mempromosikan dan mengembangkan prinsip-prinsip Islam, syariah dan tradisinya ke dalam transaksi keuangan dan perbankan dan bisnis lain yang terkait (Zainul Arifin, 2002). Berdirinya bank syariah merupakan murni keinginan umat untuk bisa bertransaksi keuangan yang terbebas dari bahaya riba dan keinginan tersebut diperjuangkan dengan berdirinya beberapa bank syariah di Indonesia. 
Sampai tahun 2018 sudah berdiri 14 Bank Umum Syariah, 20 Unit Usaha Syariah dan 167 Bank Pembiayaan Rakyat Syariah (Otoritas Jasa Keuangan, 2018).

Dawam Raharjo menyatakan perkembangan suatu lembaga keuangan ditunjukkan oleh indikator nilai aset dan pangsa pasarnya (Adiwarman Karim, 2010). Aset perbankan syariah sampai tahun 2018 berada pada kisaran 5,33 \% dibandingkan dengan aset perbankan nasional, hal ini menunjukkan bahwa pertumbuhan bank syariah belum dapat mengimbangi pertumbuhan bank konvensional. Hal ini menggambarkan bahwa perbankan syariah Indonesia masih terus perlu dikembangkan sehingga dapat bersaing dengan perbankan konvensional ( Otoritas Jasa Keuangan, 2019).

Bank Umum Syariah dan Unit Usaha Syariah memiliki fokus pembiayaan dengan skala besar, sedangkan BPRS memberikan pembiayaan kepada sektor kecil dan mikro. BPRS ditujukan untuk mendukung perekonomian usaha masyarakat kelas menengah, kecil dan mikro di pedesaan dan kota yang belum dijangkau oleh bank umum (Bank Indonesia, 2009). Tetapi pada saat ini bank umum juga telah membuka layanan mikro, yang mempengaruhi persaingan pasar sehingga berdampak kepada perkembangan BPRS.

\section{Tabel 1.1}

Variabel Penelitian dan Pertumbuhan Aset BPRS selama 2014 -2018

\begin{tabular}{|c|c|c|r|r|r|c|}
\hline Tahun & inflasi & $\begin{array}{c}\text { Suku } \\
\text { Bunga }\end{array}$ & $\begin{array}{c}\text { Equivalent } \\
\text { Rate }\end{array}$ & ROA & $\begin{array}{c}\text { Aset BPRS } \\
\text { ( Milyar Rp ) }\end{array}$ & $\begin{array}{c}\text { Pertumbuhan } \\
\text { Aset ( \%) }\end{array}$ \\
\hline 2013 & $8,38 \%$ & $7,50 \%$ & $11,66 \%$ & $2,79 \%$ & $5,833,488$ & \\
\hline 2014 & $8,36 \%$ & $7,75 \%$ & $11,71 \%$ & $2,26 \%$ & $6,573,331$ & $11 \%$ \\
\hline 2015 & $3,35 \%$ & $7,50 \%$ & $10,36 \%$ & $2,20 \%$ & $7,739,270$ & $15 \%$ \\
\hline 2016 & $3,02 \%$ & $4,75 \%$ & $10,13 \%$ & $2,27 \%$ & $9,157,801$ & $15 \%$ \\
\hline 2017 & $3,61 \%$ & $4,25 \%$ & $9,67 \%$ & $2,55 \%$ & $10,840,375$ & $16 \%$ \\
\hline 2018 & $3,13 \%$ & $6 \%$ & $9,73 \%$ & $1,87 \%$ & $12,361,734$ & $12 \%$ \\
\hline
\end{tabular}

Sumber : Statistik Perbankan Syariah Desember 2018, Otoritas Jasa Keuangan

Berdasarkan tabel di atas terlihat pertumbuhan aset BPRS mengalami stagnan pada tahun 2015 dan 2016 bahkan mengalami penurunan pertumbuhan pada tahun 2018. Oleh karena itu perlu dilakukan penelitian untuk mengetahui faktor faktor apa yang mempengaruhi pertumbuhan aset BPRS di Indonesia.

Aset sebuah bank dipengaruhi oleh berbagai faktor, diantaranya ada faktor internal yaitu kondisi dalam perusahaan seperti Equivalent Rate dan kemampuan Bank dalam meraih laba yang dilihat dari rasio ROA (return on asset) dan faktor eksternal yaitu kondisi luar perusahaan seperti inflasi dan suku bunga bank Indonesia. 
Adanya perubahan pada variabel ekonomi akan memiliki dampak terhadap variabel lainnya. Penabung akan menjadikan inflasi sebagai acuan dalam memilih produk simpanan di bank. Jika inflasi meningkat maka bank Indonesia akan meningkatkan suku bunga acuan, maka pihak perbankan pun akan menyesuaikan dengan kebijakan bank Indonesia (Gunawan, 2012).

Berdasarkan penelitian dari Indriani dengan judul "Analisis Faktor-Faktor Yang Mempengaruhi Pertumbuhan Total Aset Bank Syariah Di Indonesia” dengan hasil penelitian bahwa faktor-faktor yang mempengaruhi pertumbuhan aset bank syariah meliputi faktor pertumbuhan GDP, suku bunga riil, inflasi, rasio ROA, jumlah kantor, serta rasio NPF(Indriani, 2006).

Bertolak belakang dengan penelitian tersebut, hasil penelitian dari Diana Djuwita dan Assa Fito Mohammad dengan judul penelitian "Pengaruh Total DPK, FDR, NPF dan ROA terhadap Total Asset Bank Syariah di Indonesia” menyatakan bahwa secara bersama-sama variabel DPK, FDR, ROA, dan NPF berpengaruh signifikan terhadap total asset bank syariah. Secara parsial, hanya DPK, FDR, dan NPF yang berpengaruh signifikan, sedangkan ROA tidak berpengaruh signifikan (Diana Djuwita, 2016).

Berdasarkan hal tersebut, peneliti merasa tertarik untuk meneliti Aset Bank Pembiayaan Rakyat Syariah dengan merumuskan masalah apakah inflasi berpengaruh terhadap aset BPRS, apakah suku bunga bank Indonesia berpengaruh terhadap aset BPRS, apakah Equivalent Rate Deposito berpengaruh terhadap aset BPRS, apakah ROA berpengaruh terhadap aset BPRS.

\section{TINJAUAN TEORITIK}

\subsection{Aset}

Untuk menciptakan BPR Syariah yang kokoh dan kuat, maka perlu didukung dengan pertumbuhan aset yang cukup signifikan sehingga dapat meningkatkan pelayanan kepada masyarakat. (Anton Sudrajat, 2015) Pertumbuhan aset dimaksud salah satunya dengan meningkatkan volume pembiayaan dan simpanan. Sehingga dampaknya akan meningkatkan kepuasaan dan kepercayaan masyarakat kepada BPRS.

Kegiatan operasional bank adalah menghimpun dan menyalurkan dana dari masyarakat serta melayani jasa keuangan. Dana yang dikumpulkan oleh bank masuk ke dalam pasiva, sementara dana yang disalurkan oleh bank kepada masyarakat masuk kedalam sisi aktiva atau aset. aktiva dan pasiva harus dikelola dengan baik, oleh karena itu diperlukan manajemen yang dapat menyeimbangkan di antara keduanya. Manajemen pasiva berkaitan dengan mengelola sumber dana yang ada, sedangkan 
manajemen asset berkaitan dengan upaya bank dalam mengelola dana yang berhasil dihimpun.

\subsection{Inflasi}

Inflasi berkaitan dengan kenaikan harga secara umum. Akan tetapi kenaikan harga satu jenis barang tidak termasuk inflasi. Misalnya, kenaikan tiket pesawat pada musim libur. Karena hanya satu komoditas saja yang mengalami kenaikan, maka tidak disebut inflasi. (Bramantyo, 2008)

Inflasi diukur dengan menghitung perubahan tingkat persentase perubahan sebuah indeks harga. Salah satu indeks yang digunakan untuk mengukur inflasi adalah indeks harga konsumen (IHK). Indeks harga konsumen merupakan nomor indeks yang mengukur rata-rata dari barang dan jasa yang dikonsumsi rumah tangga.

Inflasi dapat digolongkan menjadi empat jika dilihat menurut besarnya dampak bagi ekonomi, yaitu :

1. Inflasi ringan ( inflasi dibawah $10 \%$ )

2. Inflasi sedang (antara $10 \%$ sampai $30 \%$ )

3. Inflasi berat (antara $30 \%$ sampai $100 \%$ )

4. Hiperinflasi ( diatas100 \%)

Inflasi dalam kategori ringan akan membuat semangat para produsen untuk membuat produk karena adanya kenaikan harga yang wajar, namun inflasi yang tinggi akan menggerus daya beli masyarakat dan membuat biaya tinggi bagi produsen.

\subsection{Suku Bunga Bank Indonesia (BI Rate)}

Bank konvensional seperti Bank Mandiri, BNI, dan bank lain menetapkan bunga dengan mengacu kepada suku bunga (BI Rate) yang ditetapkan oleh Bank Indonesia. Sedangkan Bank Syariah tidak menggunakan acuan BI Rate karena penerapan bunga tidak dibolehkan pada bank syariah. namun suku bunga bank Indonesia tetap memiliki dampak bagi bank syariah. Bank Indonesia menerapkan kebijakan moneter diantaranya dengan menetapkan suku bunga acuan. Bank Indonesia menaikkan bunga acuan dengan tujuan mengarahkan perbankan untuk menyesuaikan bunga deposito dan kredit. Dengan kata lain masyarakat akan dianjurkan untuk menabung daripada menghabiskan uangnya untuk dibelanjakan. Dengan kenaikan BI Rate uang yang beredar di masyarakat akan terkumpul di perbankan. (Gunawan, 2012)

Demikian juga bagi Bank Pembiayaan Rakyat Syariah yang memiliki modal dari modal sendiri atau dari bank umum yang memiliki kelebihan dana. Bila Bank Indonesia menaikkan atau menurunkan suku bunga acuan akan memiliki konsekuensi bagi bank umum dan BPRS. 


\subsection{Equivalent Rate}

Bagi hasil merupakan pembagian atas hasil usaha yang telah dilakukan oleh pihak-pihak yang melakukan perjanjian yaitu pihak nasabah dan bank syariah. pembagian hasil usaha dalam perbankan syariah ditetapkan dengan menggunakan nisbah. Nisbah yaitu persentase yang disetujui oleh kedua belah pihak dalam menentukan Equivalent Rate atas usaha yang dikerjasamakan.

Equivalent Rate yang menarik dan menguntungkan akan membuat nasabah menginvestasikan dananya pada BPRS. Nasabah akan membandingkan Equivalent Rate yang diterimanya di BPRS dengan tingkat bunga yang ditawarkan oleh bank konvensional lain. Untuk memudahkan nasabah memahami bagi hasil, dibuatlah konsep equivalent rate pada bank syariah.

Menurut Syafii Antonio, equivalent rate merupakan jumlah Bagi hasil untuk seorang nasabah perbulan dibagi dengan saldo rata-rata nasabah tersebut yang dinyatakan dalam bentuk persentase. Equivalent rate berbeda dengan bunga yang ditawarkan oleh bank konvensional. Bunga ditetapkan dari awal perjanjian,sedangkan equivalent rate dihitung pada akhir bulan setelah investasi yang dikelola memberikan keuntungan (Antonio, 2001).

\subsection{Return On Asset (ROA)}

ROA merupakan rasio untuk menyatakan kemampuan bank dalam menghasilkan laba. ROA diperoleh dengan rumus :

$$
R O A=\frac{\text { Laba Bersih setelah Pajak }}{\text { Total Aset }}
$$

Semakin besar ROA suatu bank, semakin besar pula keuntungan sebuah bank dan semakin baik penggunaan aktiva produktif sebuah bank. Aktiva produktif adalah aset yangdigunakan bank untuk menghasilkan keuntungan yaitu piutang dan pembiayaan yang disalurkan oleh bank. Semakin besar laba, maka nilai aset bank juga semakin besar.

\subsection{Penelitian Terdahulu}

Penelitian dari Ida Syafrida dan Ahmad Abror dengan judul penelitian "FaktorFaktor Internal Dan Eksternal Yang Mempengaruhi Pertumbuhan Aset Perbankan Syariah Di Indonesia" menyatakan bahwa seluruh variabel bebas yaitu jumlah kantor bank syariah, rasio NPF, rasio FDR, biaya promosi, dan jumlah dana pihak ke-tiga (DPK) yang ada di bank syariah, office chaneling dan jumlah uang beredar (M2) secara bersama-sama mampu mejelaskan variabel terikat, yaitu aset perbankan syariah. Sedangkan secara parsial hanya jumlah kantor, rasio FDR, dan biaya promosi yang mempengaruhi terhadap aset perbankan syariah. (Ida Syafrida,2011) 
Penelitian dari Anton Sudrajat dengan judul "Determinan Total Aset Bank Pembiayaan Rakyat Syariah (BPRS)di Pulau Jawa Tahun 2014” menyatakan bahwa secara simultan faktor Pembiayaan, Dana Pihak Ketiga (DPK), Financing to Deposit Ratio (FDR), dan Non Performing Financing (NPF) berpengaruh signifikan terhadap total aset BPR Syariah di Pulau Jawa. Sedangkan secara parsial, hanya faktor Pembiayaan yang berpengaruh signifikan terhadap total aset BPR Syariah di Pulau Jawa. (Anton Sudrajat, 2015)

Penelitian dari Almira Ulfa Nugraheni dengan judul "Pengaruh Equivalent Rate, Profitabilitas, dan Jumlah Kantor Terhadap Dana Pihak Ketiga BPRS Di Indonesia" menyatakan bahwa secara simultan Equivalent Rate, Profitabilitas dan Jumlah Kantor berpengaruh terhadap dana pihak ketiga BPRS, secara parsial hanya Profitabilitas dan jumlah kantor berpengaruh secara signifikan terhadap dana pihak ketiga BPRS, sedangkan Equivalent Rate tidak berpengaruh terhadap dana pihak ketiga BPRS.

Perbedaan penelitian ini dengan penelitian sebelumnya yaitu pada variabel yang peneliti gunakan yaitu inflasi dan suku bunga yang merupakan variabel eksternal di luar bank, kemudian variabel equivalent rate dan ROA yang merupakan variabel internal di dalam bank. Kemudian variabel dependen dalam penelitian ini adalah aset BPRS.

\subsection{Kerangka Pikir}

Kerangka Teoritis merupakan suatu model yang menerangkan bagaimana hubungan suatu teori dengan faktor-faktor penting yang telah diketahui dalam suatu masalah tertentu.

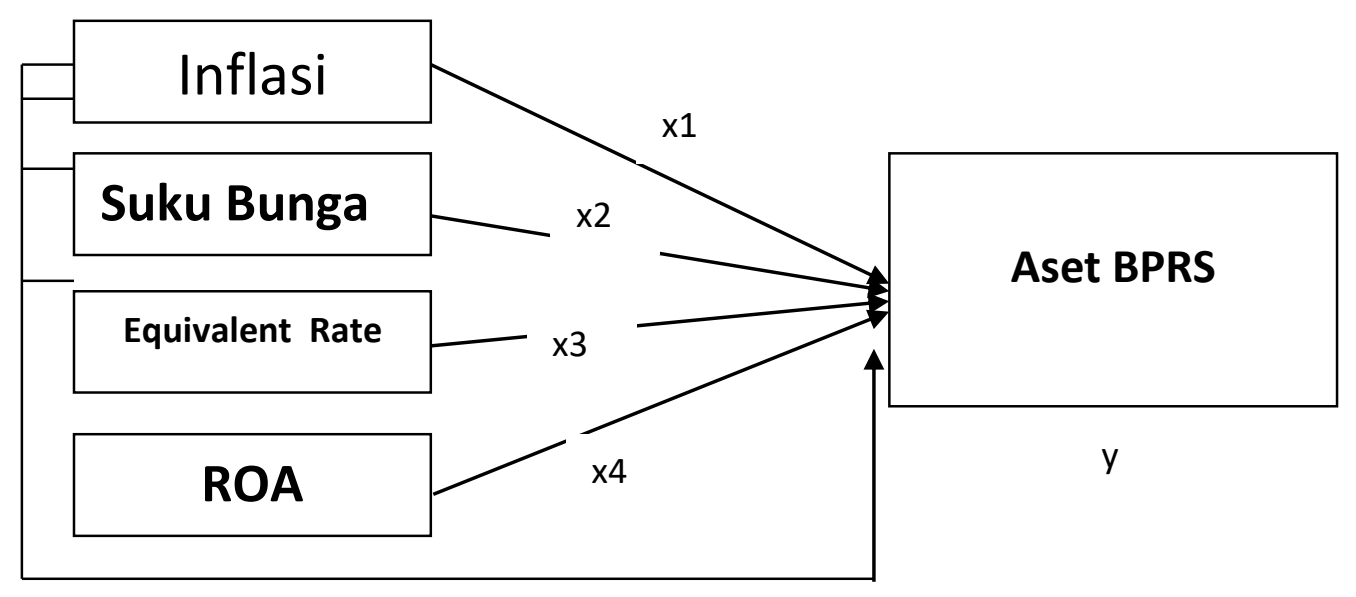

Gambar 2.1.Kerangka Pikir 
Berdasarkan kerangka teoritis ini maka penulis ingin meneliti pengaruh inflasi, BI Rate, Equivalent Rate dan ROA terhadap Aset BPRS. Adanya perubahanperubahan variabel ekonomi akan berpengaruh terhadap variabel ekonomi lainnya. Inflasi akan mendorong Bank Indonesia menaikkan BI rate, inflasi akan berpengaruh negatif terhadap pertumbuhan investasi dan perekonomian. Jika Equivalent Rate meningkat akan mengakibatkan peningkatan Dana Pihak Ketiga di Bank Syariah dan jika ROA meningkat akan meningkatkan laba bank.

\subsection{Hipotesis Penelitian}

Berdasarkan teori yang telah dijelaskan di latar belakang penelitian dan perumusan masalah dalam penelitian ini, maka hipotesis penelitian yang disusun adalah sebagai berikut :

H1 : Inflasi berpengaruh terhadap Aset BPRS

H2 : Suku Bunga berpengaruh terhadap Aset BPRS

H3 : Equivalent Rate berpengaruh terhadap Aset BPRS

H4 : ROA berpengaruh terhadap Aset BPRS

\section{METODE PENELITIAN}

Penelitian ini menggunakan pendekatan kuantitatif yaitu data yang diukur dalam skala numerik, berdasarkan data time series yang berhubungan dengan inflasi,suku bunga atau $B I$ Rate, Equivalent Rate, Return on Aset (ROA) yang bersumber dari Bank Indonesia, Badan Pusat Statistik, Otoritas Jasa Keuangan, jadi data yang digunakan dalam penelitian ini adalah data sekunder.

Populasi dari penelitian ini adalah data yang diperoleh dari Otoritas Jasa Keuangan (Aset BPRS, Equivalent Rate, ROA ), Badan Pusat Statistik (Inflasi), Bank Indonesia (Suku Bunga), periode Januari 2014 sampai Desember 2018. Teknik pengumpulan data dalam penelitian ini adalah studi dokumen. Studi dokumen dipergunakan untuk memperoleh data sekunder.

Data yang diperoleh kemudian dianalisis dengan regresi linear berganda menggunakan software eviews 8. Adapun uji yang dilakukan adalah uji asumsi klasik dan uji hipotesis. Uji asumsi klasik digunakan untuk menguji apakah data yang digunakan merupakan data linier atau tidak bias. Uji ini terdiri dari uji normalitas, Multikolinearitas, dan Autokorelasi. Sedangkan uji hipotesis dilakukan untuk menguji kebenaran hipotesis berdasarkan data penelitian. Uji ini terdiri dari uji koefisien determinasi $\left(\mathrm{R}^{2}\right)$, uji F statistik, dan uji t statistik

Data Inflasi, BI Rate, Equivalent Rate, ROA dalam bentuk persen dan Aset BPRS dalam bentuk rupiah, sehingga diperlukan keseragaman nilai tiap variabel yang berbeda-beda, 
selain itu untuk memudahkan estimasi yang lebih efisien, serta menghindari resiko terkena multikolinearitas, maka model penelitian ditransformasi ke dalam model logaritma natural, kemudian untuk mengetahui kestasioneran data dan menghindari terkenal autokorelasi maka digunakan model autoregressive (AR) sehingga model berubah menjadi :

$$
\begin{array}{ll}
\operatorname{LnY}= & a+b \operatorname{Lnx} 1+b \operatorname{LnX} 2+\mathrm{bLnX}_{3}+\mathrm{b} \mathrm{LnX}_{4}+\mathrm{AR}+\mathrm{e} \\
\mathrm{LnY} & : \text { Logaritma Natural Aset BPRS } \\
\mathrm{a} & : \text { constanta } \\
\mathrm{b} & : \text { Angka arah atau koefisien regresi } \\
\mathrm{LnX} 1 & : \text { Logaritma Natural Inflasi } \\
\mathrm{LnX} 2 & : \text { Logaritma Natural Suku Bunga } \\
\mathrm{LnX}_{3} & : \text { Logaritma Natural Equivalent rate } \\
\mathrm{LnX} 4 & : \text { Logaritma Natural ROA } \\
\mathrm{AR} \quad: \text { Auto Regressive } \\
\mathrm{e} \quad: \text { term error (faktor pengganggu) }
\end{array}
$$

\section{HASIL DAN PEMBAHASAN}

\subsection{Uji Normalitas}

Uji normalitas yang dimaksud dalam asumsi klasik dengan pendekatan OLS adalah data residual yang dibentuk model regresi linier terdistribusi normal, bukan variabel bebas ataupun variabel terikatnya, dan pengujian tersebut dapat menggunakan Jarque-Bera Test. Hasil uji normalitas dalam penelitian in dapat dilihat pada tabel berikut.

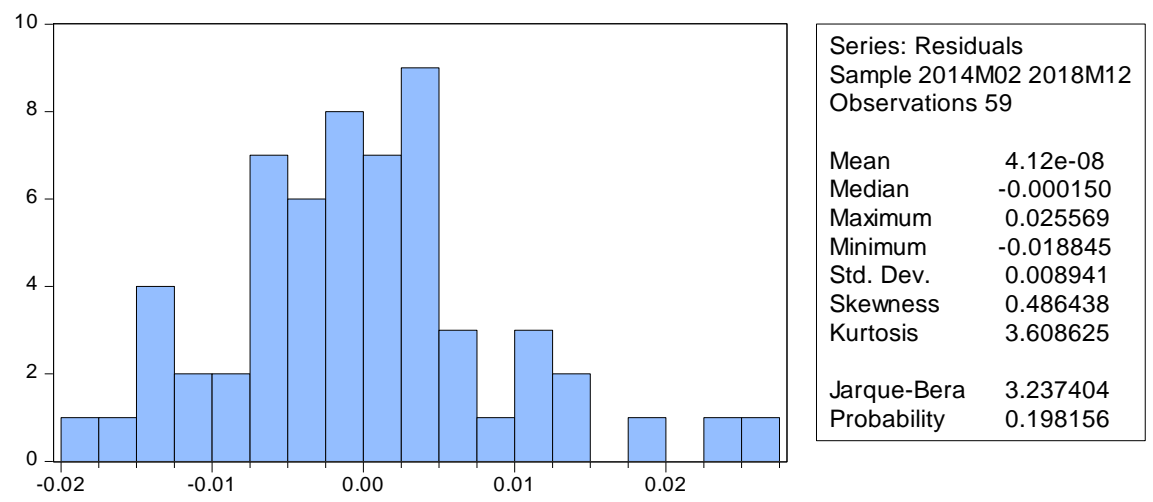

Gambar 4.1 Hasil Uji Normalitas

Dari uji normalitas diatas didapat nilai probability sebesar 0,198. Artinya data berdistribusi normal. Ini karena angka 0,198 > 0,05. Apabila angka probality > 0,05 maka data berdistribusi normal, sebaliknya apabila angka probability $<0,05$ maka data tidak berdistribusi normal. 


\subsection{Uji Asumsi Klasik}

Uji asumsi klasik digunakan untuk melihat adanya penyakit atau faktor penggangu pada variabel penelitian. Uji asumsi klasik yang digunakan yaitu uji multikolinearitas dan uji autokorelasi. Uji multikolonieritas dilakukan untuk melihat apakah antara variabel bebasnya terjadi hubungan satu sama lain dan hasil uji multikolonieritasnya dapat dilihat pada tabel berikut.

\section{Tabel 4.2}

\section{Hasil Uji Multikolonieritas}

\begin{tabular}{cc}
\hline Variabel & VIF \\
\hline \hline Inflasi & 1,062628 \\
Birate & 1,150664 \\
Equivalent rate & 1,027690 \\
ROA & 1,011307 \\
\hline
\end{tabular}

Sumber: Data diolah

hasil pengujian ini menunjukkan bahwa semua variabel bebas memiliki nilai VIF lebih kecil dari 5. Maka dapat dikatakan bahwa tidak terjadi multikolinearitas pada model regresi ini.

Setelah dilakukan uji multikolonieritas, berikut dilakukan uji autokorelasi dengan melihat nilai Durbin Watson, yang nilainya ditunjukkan pada tabel berikut.

Tabel 4.3

Hasil Uji Autokorelasi

\begin{tabular}{cccc}
\hline $\begin{array}{c}\text { Nilai } \\
\text { DW }\end{array}$ & DL & DU & Keputusan \\
\hline \hline & & & Tidak Terjadi \\
1,850157 & 1,4431 & 1,7274 & Autokorelasi \\
& & & \\
\hline
\end{tabular}

Sumber: Data diolah

Dari tabel terlihat nilai durbin Watson yaitu 1.850157. Dari hasil estimasi di atas kita dapat memperoleh nilai dw tabel lower dan upper untuk $\mathrm{k}=4$ dan $\mathrm{n}=60$, masingmasing sebesar $d l=1.4431 \mathrm{dan} d u=17274$. nilai $d \mathrm{w}=1.850157$. ini artinya nilai Dw 
terletak antara batas atas (Uppubound/Dw) dan (4 - Des), maka koefisien autokorelasi sama dengan nol, berarti tidak ada autokorelasi.

\subsection{Uji Hipotesis}

Uji hipotesis digunakan untuk menjawab berpengaruh atau tidaknya variabel independen terhadap variabel dependen baik secara parsial maupun secara simultan. Uji hipotesis yang pertama sekali digunakan adalah uji t atau pengujian secara parsial variabel independe terhadap variabel dependen seperti yang terlihat pada tabel berikut.

Tabel 4.4

Hasil Uji Parsial

\begin{tabular}{cccc}
\hline Variabel & $\begin{array}{c}\text { Nilai } \\
\text { Probability }\end{array}$ & Signifikansi & Kesimpulan \\
\hline \hline Inflasi & 0,0199 & 0,05 & Berpengaruh \\
Bi Rate & 0,2633 & 0,05 & Tidak Berpengaruh \\
Equivalent & 0,0311 & 0,05 & Berpengaruh \\
rate & 0,9112 & 0,05 & Berpengaruh \\
ROA & & &
\end{tabular}

Sumber : Data diolah

Dari tabel diatas dapat diintepretasikan bahwa :

1. Variabel inflasi memiliki nilai probability sebesar 0.0199 . jika dibandingkan dengan nilai signifikansi 0,05 maka dapat dikatakan probability inflasi lebih kecil. $0.0199<$ 0,05. Ini artinya inflasi memiliki pengaruh terhadap Aset BPRS

2. Variabel suku bunga (BI Rate) memiliki nilai probability sebesar 0.2633 - jika dibandingkan dengan nilai signifikansi o,05 t dapat dikatakan probability suku bunga lebih besar. $0.2633>0,05$. Ini artinya suku bunga tidak memiliki pengaruh terhadap Aset BPRS

3. Variabel Equivalent Rate memiliki nilai probability sebesar 0.0311 . jika dibandingkan dengan nilai signifikansi 0,05 maka dapat dikatakan probability Equivalent Rate lebih kecil. 0.0311<0,05. Ini artinya Equivalent Rate memiliki pengaruh terhadap Aset BPRS

4. Variabel ROA memiliki nilai probability sebesar 0.9112 .jika dibandingkan dengan nilai signifikansi 0,05 maka dapat dikatakan probability ROA lebih kecil. 0.9112 >0,05. Ini artinya ROA tidak memiliki pengaruh terhadap Aset BPRS 
Setelah dilakukan uji parsial berikutnya dilakukan uji simultan, melihat pengujian variable independen secara bersama-sama memiliki pengaruh simultan atau tidak. Hasil uji simultan dapat dilihat pada tabel berikut.

Tabel 4.5

Uji Secara Simultan

\begin{tabular}{cccc}
\hline F hitung & F tabel & Prob(F-statistic) & Kesimpulan \\
\hline \hline 7227,808 & 2,54 & 0,000000 & Berpengaruh \\
& & & secara simultan \\
\hline
\end{tabular}

Sumber : Data diolah

Berdasarkan hasil pengujian seperti pada tabel, menunjukkan bahwa nilai $\mathrm{F}$ hitung sebesar 7227.808 dengan probabilitas 0,000. Sementara harga F-tabel untuk jumlah data pengamatan sebanyak 60 dengan taraf signifikansi $5 \%$ dengan $\mathrm{dk}$ pembilang atau $\mathrm{k}$ (jumlah variabel bebas) $=4$, serta dk penyebut $=60(\mathrm{n}-\mathrm{k}-1)=55$, diperoleh $\mathrm{F}$ tabel sebesar 2,54 . jika F hitung dibandingkan dengan harga F tabel, maka diperoleh bahwa : 7227.808> 2,54, ini artinya secara bersama sama seluruh variabel bebas berpengaruh terhadap variabel terikat.

Setelah dilihat hasil secara parsial dan simultannya, berikut dilakukan uji koefisien determinasi, tujuannya untuk mengetahui berapa persen tingkat pengaruh variabel bebasnya terhadap variabel terikatnya. Nilai koefisien determinasinya dapat dilihat pada tabel berikut.

Tabel 4.6

Hasil Uji Koefisien Determinasi

\begin{tabular}{cc}
\hline R-Squared & \% Pengaruh \\
\hline \hline 0,998536 & $99,85 \%$ \\
\hline
\end{tabular}

Sumber: Data diolah

Pada tabel diatas terlihat nilai R squared memiliki nilai 0.998536 atau 99,85\%. Ini artinya variabel bebas yang digunakan dalam penelitian ini yaitu Inflasi, Suku Bunga, Equivalent Rate mampu menjelaskan terhadap variabel terikat yaitu Aset BPRS sebesar 99,85\%, dan sisanya 0,15 \% lagi dijelaskan oleh variabel lain yang tidak masuk dalam penelitian ini. 


\subsection{Analisis Regresi Linier Berganda}

Berdasarkan hasil pengujian kenormalitasan data, hasil uji asumsi klasik, dan hasil uji hipotesis, maka model yang terbentuk dalam penelitian ini adalah sebagai berikut.

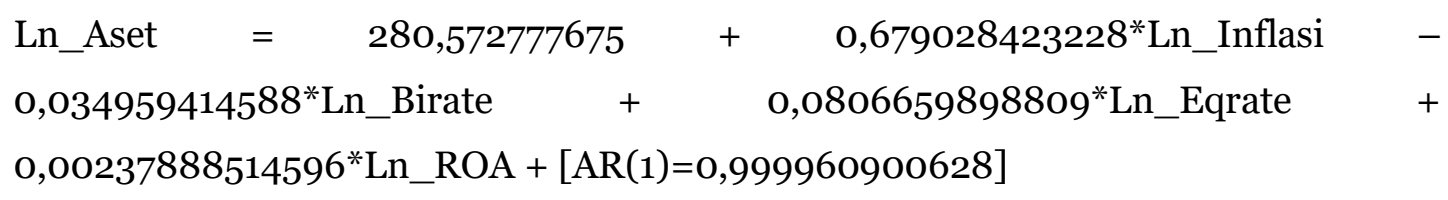

Dari persamaan regresi ini dapat diketahui hubungan antar variabel. Inflasi memiliki hubungan positif terhadap aset BPRS yaitu sebesar 0,6790. Suku bunga memiliki hubungan negatif terhadap aset BPRS yaitu sebesar - 0,034. Equivalent rate memiliki hubungan positif terhadap aset BPRS yaitu sebesar o,o8o. Kemudian ROA memiliki hubungan positif terhadap aset BPRS yaitu sebesar 0,0023.

\subsection{Pembahasan Hasil Penelitian}

Berdasarkan hasil uji hipotesis, uji t diketahui bahwa variabel inflasi memiliki hubungan positif dan berpengaruh terhadap aset BPRS. Hal diketahui dari koefisien t hitung variabel inflasi bernilai 0.679028 dengan nilai sig-t sebesar 0,0019. Nilai signifikansi t (sig t ) sebesar 0,0019 lebih kecil dari 0,05, sehingga dapat disimpulkan bahwa inflasi berpengaruh terhadap aset BPRS dan hubungannya bersifat positif artinya ketika inflasi meningkat maka nilai aset BPRS juga meningkat.

Berdasarkan hasil uji hipotesis, uji t diketahui bahwa variabel suku bunga memiliki hubungan negatif namun tidak berpengaruh terhadap aset BPRS. Hal diketahui dari koefisien t hitung variabel suku bunga bernilai -0.034959 dengan nilai sig-t sebesar 0.2633, Nilai signifikansi t (sig t ) sebesar 0.2633 lebih besar dari 0,05, sehingga dapat disimpulkan bahwa suku bunga tidak berpengaruh terhadap aset BPRS dan hubungannya bersifat negatif artinya ketika suku bunga meningkat tidak berpengaruh terhadap peningkatan aset BPRS.

Berdasarkan hasil uji hipotesis, uji t diketahui bahwa variabel equivalent rate memiliki hubungan positif dan berpengaruh terhadap aset BPRS. Hal diketahui dari koefisien thitung variabel equivalent rate bernilai 0.080666 dengan nilai sig-t sebesar o.0311), Nilai signifikansi t (sig t ) sebesar 0,0311 lebih kecil dari o,05, sehingga dapat disimpulkan bahwa equivalent rate memiliki pengaruh terhadap aset BPRS dan hubungannya bersifat positif artinya ketika equivalent rate meningkat maka nilai aset BPRS juga meningkat.

Berdasarkan hasil uji hipotesis, uji t diketahui bahwa variabel ROA memilkiki hubungan positif namun tidak berpengaruh terhadap aset BPRS. Hal diketahui dari koefisien t hitung variabel ROA bernilai 0.002379 dengan nilai sig-t sebesar 0.9112), 
Nilai signifikansi t ( sig t) sebesar 0,9112 lebih besar dari 0,05, sehingga dapat disimpulkan bahwa ROA tidak berpengaruh terhadap aset BPRS dan hubungannya bersifat positif, artinya ketika ROA meningkat maka tidak berpengaruh terhadap nilai Aset BPRS.

Bila dibandingkan dengan penelitian terdahulu yang dilakukan oleh Indriani dengan judul "Analisis Faktor-Faktor Yang Mempengaruhi Pertumbuhan Total Aset Bank Syariah Di Indonesia" dengan hasil penelitian bahwa faktor-faktor yang mempengaruhi pertumbuhan aset bank syariah meliputi faktor pertumbuhan GDP, suku bunga riil, inflasi, rasio ROA, jumlah kantor, serta rasio NPF. (Indriani, 2006). Bila dilihat maka faktor inflasi dalam penelitian ini juga berpengaruh terhadap nilai aset BPRS.

Inflasi yang terjadi di Indonesia masih dikategorikan sebagai inflasi ringan yang wajar dan ini menyebabkan kenaikan harga yang wajar.(lihat tabel 1). Kemudian suku bunga yang ditetapkan oleh bank Indonesia tidak secara langsung berpengaruh terhadap kondisi BPRS, kenaikan suku bunga mengakibatkan bank syariah menyesuaikan nilai equivalent rate untuk menjaga kestabilan dana pihak ketiga agar tidak berpindah ke bank konvensional. Ketika suku bunga naik maka bank syariah juga menyesuaikan equivalent rate, di satu sisi hal ini untuk menjaga agar nasabah tidak berpindah ke bank konvensional, namun di sisi lain hal ini menyebabkan masyarakat tidak bisa membedakan bank syariah dengan bank syariah dari sisi besarnya tingkat pengembalian yang diterima nasabah.

Hal ini bersesuaian dengan penelitian yang dilakukan oleh Susanti Vera dengan judul penelitian “ Pengaruh Equivalent Rate dan Tingkat Keuntungan Terhadap Dana Pihak Ketiga (DPK) Perbankan Syariah di Indonesia" dengan hasil penelitian bahwa equivalent rate berpengaruh terhadap dana pihak ketiga bank syariah. Untuk

terus merebut pasar mengambang yang sangat besar jumlahnya, bank syariah harus mampu berkompetisi secara sehat, yaitu menetapkan sistem bagi hasil dan equivalentrate yang dapat bersaing dengan bunga bank

konvensional (Susanti Vera, 2015). Dana Pihak ketiga akan meningkat jika BPRS menjaga nilai equivalent rate. Peningkatan Dana Pihak ketiga akan meningkat aset.

Kemampuan Bank dalam meriah laba yang ditampilkan dalam bentuk rasio ROA, tidak berpengaruh secara signifikan terhadap aset BPRS. hal ini bersesuaian dengan penelitian yang dilakukan oleh Diana Djuwita dan Assa Fito Mohammad dengan judul penelitian "Pengaruh Total DPK, FDR, NPF dan ROA terhadap Total Asset Bank Syariah di Indonesia" menyatakan bahwa secara bersama-sama variabel 
DPK, FDR, ROA, dan NPF berpengaruh signifikan terhadap total asset bank syariah. Secara parsial, hanya DPK, FDR, dan NPF yang berpengaruh signifikan, sedangkan ROA tidak berpengaruh signifikan. (Diana Djuwita, 2016) maka penelitian ini bersesuaian dengan penelitian yang dilakukan oleh Diana Djuwita dan Assa Fito Muhammad.

\section{KESIMPULAN}

Inflasi dalam kategori ringan dan wajar akan membuat gairah petumbuhan ekonomi termasuk dalam sektor keuangan seperti perbankan syariah, namun jika inflasi terus naik dan masuk dalam kategori berat, hal ini akan membuat ekonomi lesu karena daya beli masyarakat akan menurun.

Suku bunga bank Indonesia tidak berpengaruh secara langsung terhadap aset BPRS, namun perubahan suku bunga acuan akan direspon oleh bank konvensional dengan menyesuaikan suku bunga pada bank masing-masing, hal ini juga menyebabkan bank syariah berusaha menyesuaikan dengan equivalent rate untuk menjaga dana pihak ketiga. Dengan menjaga dana pihak ketiga, bank syariah dapat menjaga pertumbuhan aset.

Equivalent rate yang tinggi akan membuat masyarakat menyimpan dananya pada bank syariah, namun hal ini menyebabkan masyarakat tidak bisa membedakan secara jelas antara bank syariah dengan bank konvensional dari sisi pengembalian. Hal ini akan membuat masyarakat tidak memiliki alasan khusus untuk menyimpan dananya pada bank syariah.

Kemampuan bank untuk meriah laba yang disimbolkan dengan rasio ROA tidak berpengaruh terhadap kenaikan tingkat laba, karena ROA yang fluktuatif bahkan cenderung menurun hal ini membuat ROA tidak mendorong peningkatan pertumbuhan aset BPRS.

Berdasarkan hasil analisis yang telah dilakukan dan adanya beberapa keterbatasan dalam penelitian ini, maka peneliti memberikan beberapa saran yaitu :

1. Bagi pemerintah untuk menjaga kondisi ekonomi karena dengan kondisi ekonomi yang baik akan mendukung perkembangan Bank Pembiayaan Rakyat Syariah

2. Penelitian selanjutnya dapat digunakan variabel independen lain yang secara teori merupakan faktor yang berpengaruh terhadap perkembangan aset Bank Pembiayaan Rakyat Syariah

3. Untuk peneliti selanjutnya yang akan mengambil masalah mengenai aset BPRS, penelitian dilakukan dengan menggunakan periode pengamatan yang lebih panjang dan menggunakan sampel yang lebih banyak sehingga dihasilkan kesimpulan yang lebih valid. 


\section{DAFTAR PUSTAKA :}

\section{Daftar Buku :}

Antonio, Syafii.2001. Bank Syariah Dari Teori ke Praktik, Jakarta : Gema Insani Press.

Arifin, Zainul .2002. Dasar-Dasar Manajemen Bank Syariah, Jakarta: Alvabet, 2002.

Badan Pusat Statistik, Indeks Harga Konsumen dan Inflasi Bulanan Indonesia, diakses dari laman : https://www.bps.go.id/statictable/2009/06/15/907/indeks-harga-konsumen-daninflasi-bulanan-indonesia-2005-2019.html

Bank Indonesia, Suku Bunga Bank Indonesia, di akses dari laman : https://www.bi.go.id/id/statistik/seki/terkini/moneter/Contents/Default.aspx

Djohanputro, Bramantyo. 2008. Prinsip-prinsip Ekonomi Makro, Jakarta : Penerbit PPM.

Gunawan dan Wilastomo. 2012. Mega, Memahami Ekonomi dengan Mudah, Jakarta : Penerbit Andi.

Rahardjo, M. Dawam. 2010. Menegakkan Syariat Islam Di Bidang Ekonomi, dalam Adiwarman A. Karim, Bank Islam Analisis Fiqh dan Keuangan, Jakarta : Raja Grafindo.

Otoritas Jasa Keuangan, Roadmap Pengembangan Keuangan Syariah Indonesia 2017-2019, diakses dari laman : https://www.ojk.go.id/id/kanal/syariah/berita-dankegiatan/publikasi/Pages/Roadmap-Pengembangan-Keuangan-Syariah-Indonesia-20172019.aspx pada tanggal 27April 2019

OJK, Statistik Perbankan Syariah Desember 2018, diakses dari laman https://www.ojk.go.id/id/kanal/syariah/data-dan-statistik/statistik-perbankansyariah/Default.aspx

Peraturan Bank Indonesia Nomor 11/23/Pbi/2009 Tentang Bank Pembiayaan Rakyat syariah diakses dari https://www.bi.go.id/id/peraturan/perbankan/pages/pbi_112309.aspx

\section{Daftar Jurnal :}

Aisy , Diamantin Rohadatul dan Mawardi Imron, Faktor - Faktor Yang Mempengaruhi Pertumbuhan Aset Bank Syariah Di Indonesia Tahun 2006-2015, ( Surabaya : Jurnal Ekonomi Syariah Teori dan Terapan, Vol 3 No 3, 2016)

Djuwita, Diana dan Mohammad, Assa Fito, pengaruh Total DPK, FDR, NPF dan ROA terhadap Total Asset Bank Syariah di Indonesia,(Cirebon : Jurnal Al Amwal, Vol 8 No. 1, 2016)

Syafrida, Ida dan Abror, Ahmad, Faktor-Faktor Internal Dan Eksternal Yang Mempengaruhi Pertumbuhan Aset Perbankan Syariah Di Indonesia, (Jakarta : jurnal ekonomi dan bisnis, vol 10, no. 1, juni 2011)

Sudrajat, Anton, Determinan Total Aset Bank Pembiayaan Rakyat Syariah (BPRS ) di Pulau Jawa Tahun 2014, (Islamic Economics Journal, Vol. 1 No 1. 2015) 
82 | Analisis Faktor-Faktor Yang Memengaruhi Aset BPRS

Susanti, Vera, Pengaruh Equivalent Rate dan Tingkat Keuntungan Terhadap Dana Pihak Ketiga (DPK) Perbankan Syariah diIndonesia, (Palembang : Jurnal I- Finance, Vol 1 No. 1, 2015) 